\title{
Ankara-İzmir-İstanbul'da İşveren Ve Kendi Hesabına Çalışan Kadınlar (Kadın Girişimciler) Ve Swot Analizi İle Değerlendirilmesi
}

\author{
Employer And Self-Employed Women (Women Entrepreneurs) \\ In Ankara-Izmir-Istanbul And Their Evaluation Using \\ Swot Analysis
}

Sevtap KESKÍN*

\section{Özet}

$\mathrm{Bu}$ çalışmada Türkiye İstatistik Kurumu verileri kullanılarak Türkiye'nin en gelişmiş üç ilinde; Ankara, İzmir, İstanbul'da kadın girişimciler hakkında genel bilgi, tablo ve grafiklerle ortaya konularak durum tespiti yapılmıştır. Ayrıca Ankara, İzmir, İstanbul illeri için kadın girişimcilerin güçlü- zayıf yanları, firsat ve tehditler SWOT analizi ile ortaya konulmuştur.

Anahtar Kelimeler: Kadın Girişimciler, Girişimcilik, SWOT

\section{Abstract}

In this study, using data of Turkish Statistical Institute, for the most advanced three cities of Turkey; Ankara, Izmir, Istanbul, general information about women entrepreneurs, tables and graphs were made to put forth the due diligence. Furthermore for the cities Ankara, İzmir and Istanbul, strong-weak sides and threats-opportunities of women entrepreneurs, have been presented by SWOT analysis.

Keywords: Women Entrepreneurs, Entrepreneurship, SWOT

\section{Giriş}

Girişimcilik kadınların özgürleşmesinde önemli bir rol oynadığg gibi toplum içinde yer edinmelerinin de önemli bir yoludur. Günümüzde girişimcilik faaliyetleri bir bölgenin ve şehrin gelişimine önemli katkı sağlamaktadır.

* Dr., keskinsevtap@yahoo.com 
Türkiye'de toplam nüfusun yarısını kadınlar oluşturmaktadır. Nüfusun yarısını oluşturan kadınların girişimcilik potansiyelinin ortaya çıkarılmasının ve önlerinin açılmasının il istihdamına ve ekonomisine katkısı olacaktır.

\section{Ankara-İzmir-İstanbul İllerinde Nüfus ve İstihdam}

Ülkemizin en gelişmiş illeri sıralamasında, İstanbul, Ankara ve İzmir ilk üç sırayı paylaşmaktadır. İstanbul, Türkiye'de en gelişmiş merkez olup ve tüm yerleşme merkezleri ile doğrudan ya da dolaylı ilişki içinde tüm Türkiye'yi etkisi altına almaktadır (Kulaksız, 2008, s.8). İstanbul, Türkiye'nin sanayi, ticaret, ulaşım, komünikasyon ve finans merkezidir (http://www.istanbul.gov.tr/images/docs/ii-Rapor-enson-1ppt, Erişim Tarihi:08.07.2014). Ankara ise, ülkenin Başkent'i ve İç Anadolu Bölgesi'nin hizmet ve ticaret merkezidir (Kulaksız, 2008, s.29). İzmir liman kenti olmasının yanında, hammadde kaynakları, nitelikli işgücü, ulaşım imkanlarının zenginliği ve sanayinin gelişmesine imkan veren yapısıyla, Ege bölgesinin ticaret merkezi durumunda ve Türkiye'nin en gelişmiş kentlerinden birisidir (Türkyılmaz, http://www.aksam.tr/ekonomicanli-diplomalilar-issiz--6811h.html, Erişim Tarihi:08.07.2014).

Ankara, İzmir, İstanbul illeri şehirleşme oranı, yıllık nüfus artış hızı, kişi başına gayri safi yurtiçi hasıla bakımından Türkiye ortalamalarının üstündedir (TÜİK Ankara, TÜİK İzmir, TÜİK İstanbul, 2009, 2012, 2013). 2013 y1lı verilerine göre sanayi sektöründe çalışanların toplam istihdam oranı İstanbul ve İzmir'de Türkiye ortalamasının üstünde Ankara'da Türkiye ortalamasının altında, üç ilde hizmetler sektöründe çalışanların toplam istihdam oranı Türkiye ortalamasının üstünde tarım sektöründe çalışanların toplam istihdam oranı Türkiye ortalamasının altındadır (TÜIKK Haber Bülteni, 2013). Ocak 2012'de il bazında kayıtlı istihdamın en fazla olduğu 3 il, İstanbul yüzde 30,1 (3 milyon 295 bin), Ankara yüzde 8,4 (919 bin) ve İzmir yüzde 6,6 (728 bin) olarak suralanmaktadır (TEPAV, 2012, s.3). Türkiye'deki işyerlerinin yüzde 29,2'i İstanbul'da (416 bin), yüzde 7,9'u Ankara'da (113 bin) ve yüzde 7,2'i de İzmir'de (103 bin) faaliyet göstermektedir. (TEPAV, 2012, s.4).

2013 y1lında toplam nüfusun yüzde 18,5 'i olan 14.160 bini İstanbul'da, yüzde 6,6's1 olan 5.045 bini Ankara'da, yüzde 5,3'ü olan 4.061 bini İzmir ilinde ikamet etmektedir (TÜIKK Haber Bülteni, 2014). Ankara ve İzmir illerinde kadın nüfusu erkek nüfusundan fazla, İstanbul ilinde ise erkek nüfusu kadın nüfusundan fazladır. 
- YALOVA SOSYAL BILIIMLER DERGİSI

Tablo 1: Kadın ve Erkek Nüfusu 2013

\begin{tabular}{|c|c|c|c|c|c|c|}
\cline { 2 - 7 } \multicolumn{1}{c|}{} & \multicolumn{2}{c|}{ Ankara } & \multicolumn{2}{c|}{ Izmir } & \multicolumn{2}{c|}{ İstanbul } \\
\cline { 2 - 7 } & Kadın & Erkek & Kadın & Erkek & Kadın & Erkek \\
\cline { 2 - 7 } & 2.537 .558 & 2.507 .525 & 2.033 .740 & 2.027 .334 & 7.044 .746 & 7.115 .721 \\
\hline$\%$ & 50,3 & 49,7 & 50,1 & 49,9 & 49,7 & 50,3 \\
\hline
\end{tabular}

Kaynak: TÜİK Nüfus İstatistikleri, http://www.tuik.gov.tr, Erişim Tarihi:09.07.2014.

Ankara, İzmir, İstanbul'da nüfusun hem kadınlarda hem de erkeklerde 3034 yaş diliminde en fazla olduğu tablo 2'de görülmektedir.

Tablo 2: Kadın ve Erkek Nüfusunun Yaşa Göre Dağılımı 2013(Bin)

\begin{tabular}{|c|c|c|c|c|c|c|}
\cline { 2 - 7 } \multicolumn{1}{c|}{} & \multicolumn{2}{c|}{ Ankara } & \multicolumn{2}{c|}{ İzmir } & \multicolumn{2}{c|}{ İstanbul } \\
\hline Yaş & Kadın & Erkek & Kadın & Erkek & Kadın & Erkek \\
\hline $0-4$ & 174.114 & 183.983 & 126.679 & 132.467 & 536.055 & 567.218 \\
\hline $5-9$ & 177.972 & 188.262 & 127.025 & 134.280 & 527.046 & 557.802 \\
\hline $10-14$ & 179.629 & 189.363 & 127.301 & 135.061 & 517.048 & 549.855 \\
\hline $15-19$ & 188.581 & 196.490 & 139.313 & 150.208 & 527.760 & 566.464 \\
\hline $20-24$ & 200.906 & 209.161 & 149.218 & 161.907 & 567.087 & 556.727 \\
\hline $25-29$ & 218.591 & 217.941 & 161.761 & 166.141 & 664.216 & 671.518 \\
\hline $30-34$ & 230.453 & 227.566 & 178.715 & 180.698 & 710.359 & 731.494 \\
\hline $35-39$ & 210.322 & 208.244 & 167.496 & 168.999 & 616.701 & 639.368 \\
\hline $40-44$ & 195.615 & 190.622 & 155.498 & 152.858 & 538.413 & 557.662 \\
\hline $45-49$ & 175.747 & 172.749 & 142.230 & 141.763 & 448.145 & 466.261 \\
\hline $50-54$ & 155.932 & 154.080 & 133.555 & 133.613 & 379.427 & 388.157 \\
\hline $55-59$ & 125.786 & 123.941 & 116.890 & 115.489 & 305.811 & 302.878 \\
\hline $60-64$ & 95.216 & 89.902 & 94.083 & 89.425 & 225.757 & 212.427 \\
\hline $65-69$ & 70.575 & 60.456 & 71.184 & 64.687 & 163.215 & 140.346 \\
\hline $70-74$ & 52.236 & 40.990 & 51.698 & 42.988 & 117.451 & 90.143 \\
\hline $75-79$ & 37.844 & 25.987 & 40.353 & 28.764 & 85.186 & 57.803 \\
\hline $80-84$ & 29.108 & 19.042 & 30.402 & 18.893 & 67.594 & 40.273 \\
\hline $85-89$ & 14.515 & 7.125 & 15.611 & 7.273 & 35.283 & 15.231 \\
\hline $90+$ & 4.416 & 1.621 & 4.728 & 1.820 & 12.192 & 4.094 \\
\hline
\end{tabular}

Kaynak: TÜIKK Nüfus İstatistikleri, http://www.tuik.gov.tr, Erişim Tarihi:09.07.2014.

Ankara, İzmir, İstanbul illeri nüfusunun 2013 yılı itibariyle yaş grupları ve cinsiyete göre oranlarına baktığımızda aşağıda tablo 3 'de görüldüğü gibi 
Ankara'da kadın nüfusunun yüzde 21'i 0-14 yaş grubu, yüzde 70,8'i 15-64 yaş grubu, yüzde 8,2'si 65+ yaş grubu arasındadır. Erkek nüfusunun ise yüzde 22,4'ü 0-14 yaş grubu, yüzde 71,4'ü 15-64 yaş grubu, yüzde 6,2'si 65+yaş grubu arasındadır. İzmir'de kadın nüfusunun yüzde 18,7'si 0-14 yaş grubu, yüzde 70,8'i 15-64 yaş grubu, yüzde 10,5'i 65+ yaş grubu arasındadır. Erkek nüfusunun yüzde 19,8'i 0-14 yaş grubu, yüzde 72,1'i 15-64 yaş grubu, yüzde 8,1'i 65+ yaş grubu arasındadır. İstanbul'da kadın nüfusunun yüzde 22,4'u 0-14 yaş grubu, yüzde 70,8'i 15-64 yaş grubu, yüzde 6,8'i 65+ yaş grubu arasındadır. Erkek nüfusunun ise yüzde 23,5'i 0-14 yaş grubu, yüzde 71,6's1 15-64 yaş grubu, yüzde 4,9'u 65+ yaş grubu arasındadır (TÜİK Nüfus İstatistikleri, http://www.tuik.gov.tr, Erişim Tarihi:09.07.2014).

Tablo: 3 Kadın ve Erkek Nüfusunun Yaşa Göre Dağılımı 2013\%

\begin{tabular}{|c|r|r|r|r|r|r|}
\cline { 2 - 7 } \multicolumn{1}{c|}{} & \multicolumn{2}{c|}{ Ankara } & \multicolumn{2}{c|}{ İzmir } & \multicolumn{2}{c|}{ İstanbul } \\
\hline Yaş & \multicolumn{1}{c|}{ Kadın } & \multicolumn{1}{c|}{ Erkek } & \multicolumn{1}{c|}{ Kadın } & \multicolumn{1}{c|}{ Erkek } & \multicolumn{1}{c|}{ Kadın } & \multicolumn{1}{c|}{ Erkek } \\
\hline $0-14$ & 21,0 & 22,4 & 18,7 & 19,8 & 22,4 & 23,5 \\
\hline $15-64$ & 70,8 & 71,4 & 70,8 & 72,1 & 70,8 & 71,6 \\
\hline $65+$ & 8,2 & 6,2 & 10,5 & 8,1 & 6,8 & 4,9 \\
\hline
\end{tabular}

Kaynak: TÜİK Nüfus İstatistikleri, http://www.tuik.gov.tr, Erişim Tarihi:09.07.2014.

2013 yılı itibariyle kadınlarda işgücüne katılma oranı Ankara'da yüzde 28,5, İzmir'de yüzde 38,7, İstanbul'da yüzde 30,5, istihdam oran1 Ankara'da yüzde 23,9, İzmir'de yüzde 30, İstanbul'da yüzde 26, işsizlik oranı Ankara'da yüzde 16,2, İzmir'de yüzde 22,5, İstanbul'da yüzde 14,8 olarak gerçekleşmiştir. Üç ilde kadınların işgücüne katılım ve istihdam oranının kentlerde kadınların işgücüne katılım ve istihdam oranı ortalamasının (işgücüne katılım: yüzde 28 ve istihdam: yüzde 23,4) üzerinde olması olumlu bir durumdur. Ancak, Ankara ve İstanbul'da kadınların işgücüne katılım ve istihdamının Türkiye ortalamasına (işgücüne katılım: yüzde 30,8 ve istihdam: yüzde 27,1) erişemediğini, İzmir'de ise geçtiğini görmekteyiz. Üç ilde kadın işsizlik oranı Türkiye ortalamasının (yüzde 11,9) üstünde, kent kadın işsizlik ortalamasının (yüzde 16,4) Ankara ve İstanbul altında, İzmir ise üstündedir. 
$170 \bullet$ YALOVA SOSYAL BİLİMLER DERGİSİ

Tablo 4: 2013 Yllı İtibariyle Ankara, İzmir, İstanbul'da Kurumsal Olmayan Nüfus İçinde Kadınların İşgücüne Katılım, İstihdam ve İşsizlik Oranı

\begin{tabular}{|l|c|c|c|}
\hline & Ankara & İzmir & İstanbul \\
\hline 15+Yaş Üstü Nüfus(Bin) & 1.908 & 1.635 & 5.033 \\
\hline İşgücüne Dahil Olmayan Nüfus(Bin) & 1.365 & 1.002 & 3.497 \\
\hline İşü̈cü(Bin) & 543 & 632 & 1.536 \\
\hline İstihdam(Bin) & 455 & 490 & 1.308 \\
\hline İşsiz(Bin) & 88 & 142 & 228 \\
\hline İsgücüne Katılma Oranı \% & 28,5 & 38,7 & 30,5 \\
\hline İstihdam Oranı \% & 23,9 & 30,0 & 26,0 \\
\hline İşsizlik Oranı \% & 16,2 & 22,5 & 14,8 \\
\hline
\end{tabular}

Kaynak: TÜİK, İşgücü İstatistikleri Veri Tabanı, http://www.tuik.gov.tr, Erişim Tarihi:09.07.2014.

\section{Ankara-İzmir-İstanbul'da İşveren ve Kendi Hesabına Çalışan}

\section{Kadın Sayısı}

Girişimcilik, kadınların kendi yetenek ve potansiyellerini keşfedebileceği, bağımsız karar alabilecekleri bir iştir (Çakıcı, 2006, s.59). Kadın girişimci denildiğinde akla sadece başarılı işlere imzasını atmış işveren kadınlar değil, kendi hesabına çalışan kadınlarda gelmelidir. Buna uygun olarak üç ilde 2013 yılında istihdamın işteki konuma ve cinsiyete göre dağılımına baktığımızda aşağıda tablo 5'de görüldüğü gibi Ankara'da tüm işverenler ve kendi hesabına çalışanlar içinde kadınların oranı yüzde 14,3, erkeklerin oranı yüzde 85,7'dir. İzmir'de tüm işverenler ve kendi hesabına çalışanlar içinde kadınların oranı yüzde 21,3 , erkeklerin oranı yüzde $78,7^{\prime}$ 'dir. İstanbul'da ise tüm işverenler ve kendi hesabına çalışanlar içinde kadınların oranı yüzde 14,4, erkeklerin oranı yüzde 85,6'dır. 2013 yılında il bazında tüm işverenler ve kendi hesabına çalışanlar içinde işveren ve kendi hesabına çalışan kadınların oranının en yüksek olduğu il İzmir'dir. İstanbul ikinci sırada Ankara üçüncü sırada yer almaktadır. 2013 yılında üç il bazında tüm işverenler ve kendi hesabına çalışanlar içinde işveren ve kendi hesabına çalışan erkeklerin oranının en yüksek olduğu il Ankara'dır. İstanbul ikinci sırada, İzmir üçüncü sırada yer almaktadır. 
Tablo 5: 2013 Yılı Ankara-İzmir-İstanbul'da Kadın İstihdamının İşteki Konuma ve Cinsiyete Göre Dağılımı

\begin{tabular}{|c|c|c|c|c|c|c|}
\hline Ankara & $\begin{array}{l}\text { Kadın } \\
\text { (Bin) }\end{array}$ & $\begin{array}{l}\text { Toplam } \\
\text { İstihdam } \\
\text { İçindeki } \\
\text { Pay(\%) }\end{array}$ & $\begin{array}{l}\text { Erkek } \\
\text { (Bin) }\end{array}$ & $\begin{array}{l}\text { Toplam } \\
\text { İstihdam } \\
\text { İçindeki } \\
\text { Pay(\%) }\end{array}$ & $\begin{array}{l}\text { Toplam } \\
\text { (Bin) }\end{array}$ & $\%$ \\
\hline Ücretli ve Maaşlı & 390 & 28,5 & 979 & 71,5 & 1.369 & 100.0 \\
\hline İşveren ve Kendi Hesabına & 36 & 14,3 & 215 & 85,7 & 251 & 100.0 \\
\hline Ücretsiz Aile İşçisi & 30 & 63,8 & 17 & 36,2 & 47 & 100.0 \\
\hline İzmir & $\begin{array}{l}\text { Kadın } \\
\text { (Bin) }\end{array}$ & $\begin{array}{l}\text { Toplam } \\
\text { İstihdam } \\
\text { İçindeki } \\
\text { Pay(\%) }\end{array}$ & $\begin{array}{l}\text { Erkek } \\
\text { (Bin) }\end{array}$ & $\begin{array}{l}\text { Toplam } \\
\text { İstihdam } \\
\text { İçindeki } \\
\text { Pay(\%) }\end{array}$ & $\begin{array}{l}\text { Toplam } \\
\text { (Bin) }\end{array}$ & $\%$ \\
\hline Ücretli ve Maaşlı & 330 & 31,0 & 734 & 69,0 & 1.064 & 100.0 \\
\hline İşveren ve Kendi Hesabına & 70 & 21,3 & 259 & 78,7 & 329 & 100.0 \\
\hline Ücretsiz Aile İşçisi & 90 & 74,4 & 31 & 25,6 & 121 & 100.0 \\
\hline İstanbul & $\begin{array}{l}\text { Kadın } \\
\text { (Bin) }\end{array}$ & $\begin{array}{l}\text { Toplam } \\
\text { İstihdam } \\
\text { İçindeki } \\
\text { Pay(\%) }\end{array}$ & $\begin{array}{l}\text { Erkek } \\
\text { (Bin) }\end{array}$ & $\begin{array}{l}\text { Toplam } \\
\text { İstihdam } \\
\text { İçindeki } \\
\text { Pay(\%) }\end{array}$ & $\begin{array}{l}\text { Toplam } \\
\text { (Bin) }\end{array}$ & $\%$ \\
\hline Ücretli ve Maaşlı & 1.169 & 30,0 & 2.687 & 70,0 & 3.856 & 100.0 \\
\hline İşveren ve Kendi Hesabına & 109 & 14,4 & 647 & 85,6 & 756 & 100.0 \\
\hline Ücretsiz Aile İşçisi & 30 & 63,8 & 17 & 36,2 & 47 & 100.0 \\
\hline
\end{tabular}

Kaynak: TÜİK, İşgücü İstatistikleri Veri Tabanı, http://www.tuik.gov.tr, Erişim Tarihi:11.07.2014.

Üç ilde 2004-2013 yılları arasında işveren ve kendi hesabına çalışan kadın sayısına baktığımızda tablo 6'da görüldüğü gibi Ankara'da 2004'de işveren ve kendi hesabına çalışan kadınların toplam sayısı 19 bin, 2013 yılında 36 bin, İzmir'de işveren ve kendi hesabına çalışan kadınların toplam sayısı 2004'de 21 bin, 2013 yılında 70 bin, İstanbul'da işveren ve kendi hesabına çalışan kadınların toplam sayısı 2004'de 44 bin, 2013 yılında 109 bin'dir (TÜİK 19232009 İstatistik Göstergeler, s.142, TÜİK İstatistik Y1llı̆̆ 2009, s.181, TÜİK İstatistik Y1llığg1 2011, s.171, TÜİK İstatistik Y1llığg 2012, s.183, TÜİK İşgücü İstatistikleri Veri Taban1, http://www.tuik.gov.tr, Erişim Tarihi:11.07.2014). İşveren ve kendi hesabına çalışan kadınların toplam sayısının en fazla oldu- 
ğu il İstanbul'dur. İzmir ikinci sırada Ankara üçüncü sırada yer almaktadır. 2004-2013 yılları arasında üç ilde işveren ve kendi hesabına çalışan kadınların Türkiye'de işveren ve kendi hesabına çalışan kadınlar içindeki payı dönemler itibariyle farklılıklar arz etmektedir. 2013 yılında üç ilde işveren ve kendi hesabına çalışan kadınların ülke içindeki payına baktığımızda; Ankara'nın yüzde 3,9, İzmir'in yüzde 7,7 İstanbul'un ise yüzde 11,9 olduğu görülmektedir.

\section{Tablo 6: Yıllara Göre Ankara-İzmir-İstanbul'da İşveren ve Kendi Hesabına} Çalışan Kadın (Bin) ve Türkiye İçindeki Yerleri \%

\begin{tabular}{|c|c|c|c|c|c|c|c|}
\hline \multirow{2}{*}{ Yıl } & \multirow{2}{*}{ Türkiye } & \multicolumn{2}{|c|}{ Ankara } & \multicolumn{2}{c|}{ İmir } & \multicolumn{2}{c|}{ İstanbul } \\
\cline { 3 - 8 } & & Bin & \% & Bin & \% & Bin & $\%$ \\
\hline 2004 & 539 & 19 & 3,5 & 21 & 3,9 & 44 & 8,2 \\
\hline 2005 & 717 & 17 & 2,4 & 19 & 2,6 & 48 & 6,7 \\
\hline 2006 & 729 & 24 & 3,3 & 29 & 4,0 & 59 & 8,1 \\
\hline 2007 & 692 & 20 & 2,9 & 30 & 4,3 & 46 & 6,6 \\
\hline 2008 & 693 & 22 & 3,2 & 28 & 4,0 & 52 & 7,5 \\
\hline 2009 & 827 & 29 & 3,5 & 33 & 4,0 & 76 & 9,2 \\
\hline 2010 & 905 & 42 & 4,6 & 44 & 4,9 & 94 & 10,4 \\
\hline 2011 & 902 & 36 & 4,0 & 47 & 5,2 & 99 & 11,0 \\
\hline 2012 & 882 & 34 & 3,9 & 48 & 5,4 & 117 & 13,3 \\
\hline 2013 & 915 & 36 & 3,9 & 70 & 7,7 & 109 & 11,9 \\
\hline
\end{tabular}

Kaynak: TÜIK 1923-2009 İstatistik Göstergeler, s.142, TÜİK İstatistik Yıllığı 2009, s. 181, TÜ̇iK İstatistik Yıllığı 2011, s.171, TÜİK İstatistik Yıllığı 2012 s.183, TÜİK İşgücü İstatistikleri Veri Tabanı, http://www.tuik.gov.tr, Erişim Tarihi:11.07.2014.

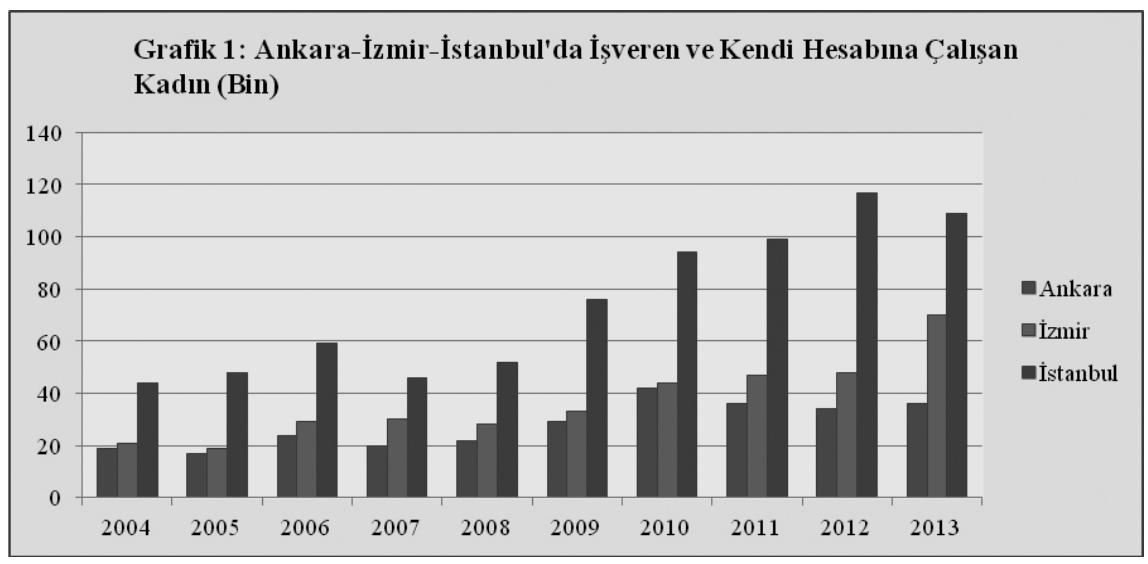

Kaynak: TÜİK 1923-2009 İstatistik Göstergeler, s.142, TÜİK İstatistik Y1llığı 2009, s.181, TÜİK İstatistik Y1llığı 2011, s.171, TÜIKK İstatistik Y1llığ 2012 s.183, TÜİK İşgücü İstatistikleri Veri Tabanı, http://www.tuik.gov.tr, Erişim Tarihi:11.07.2014. 


\section{Ankara-İzmir-İstanbul'da İşveren ve Kendi Hesabına Çalışan}

\section{Kadınların Tarım ve Tarım Dışı Ayrımına Göre Durumu}

İşveren ve kendi hesabına çalışan kadın sayısının tarım ve tarım dışı şeklinde ayrımına baktığımızda tablo 7'de görüldüğü gibi işveren ve kendi hesabına çalışan kadın sayısının İstanbul'da hemen hemen tamamının Ankara ve İzmir'de de büyük çoğunluğun tarım dışı alanlarda çalıştığ 1 görülmektedir. Bunda, üç ilde şehirleşme oranının yüksek olmasının payı vardır. İstanbul'da şehirde yaşayanların oranı yüzde 99 , köyde yaşayanların oranı yüzde 1'dir (TÜIK İstanbul, 2012, s.XVI). Ankara'da şehirde yaşayanların oranı yüzde 97,51 köyde yaşayanların oranı yüzde 2,49 'dur (TÜİK Ankara, 2012, s.XII). İzmir'de şehirde yaşayanların oranı yüzde 91, köyde yaşayanların oranı yüzde 9'dur. (TÜİK İzmir, 2012, s.XII).

Türkiye genelinde 2013 yılında tarım dışı alanda işveren ve kendi hesabına çalışan toplam kadın sayısı 505 bin'dir. 2013 yılında tarım dışı alanda işveren ve kendi hesabına çalışan toplam kadın sayısı; İstanbul'da 107 bin, İzmir'de 61 bin, Ankara'da 33 bin'dir (TÜİK İşgücü İstatistikleri Veri Tabanı, http:// www.tuik.gov.tr, Erişim Tarihi: 11.07.2014). Türkiye'de 2013 yılında tarım dışı alanda işveren ve kendi hesabına çalışan kadınların yüzde 39,8'i İstanbul, İzmir ve Ankara' da bulunmaktadır.

Türkiye genelinde 2013 yılında tarımda işveren ve kendi hesabına çal1şan toplam kadın sayısı 411 bin'dir. 2013 yılında tarımda işveren ve kendi hesabına çalışan toplam kadın sayısı; İzmir'de 10 bin, Ankara'da 3 bin, İstanbul'da 2 bin'dir (TÜİK İşü̈cü İstatistikleri Veri Tabanı, http://www.tuik. gov.tr, Erişim Tarihi:11.07.2014). Türkiye'de 2013 yılında tarımda işveren ve kendi hesabına çalışan kadınların yüzde 3,6'sı Ankara, İzmir ve İstanbul'da bulunmaktadir.

Tablo 7: Yıllara Göre Ankara-İzmir-İstanbul'da Tarım ve Tarım Dışı İşveren ve Kendi Hesabına Çalışan Kadın (Bin)

\begin{tabular}{|l|c|c|c|c|c|c|c|c|}
\hline \multirow{2}{*}{ Yıl } & \multicolumn{4}{|c|}{ Tarım } & \multicolumn{4}{c|}{ Tarım Dışı } \\
\cline { 2 - 10 } & Türkiye & Ankara & İzmir & İstanbul & Türkiye & Ankara & İzmir & İstanbul \\
\hline 2004 & 343 & 2 & 4 & 0 & 197 & 17 & 17 & 44 \\
\hline 2005 & 453 & 2 & 4 & 0 & 264 & 15 & 15 & 48 \\
\hline 2006 & 444 & 3 & 4 & 0 & 284 & 21 & 25 & 59 \\
\hline 2007 & 444 & 3 & 3 & 0 & 248 & 17 & 26 & 46 \\
\hline 2008 & 414 & 2 & 3 & 0 & 280 & 20 & 25 & 52 \\
\hline 2009 & 415 & 1 & 3 & 0 & 412 & 28 & 31 & 76 \\
\hline 2010 & 436 & 3 & 3 & 1 & 470 & 38 & 40 & 93 \\
\hline
\end{tabular}


174 • YALOVA SOSYAL BİLİMLER DERGİSİ

\begin{tabular}{|l|l|l|l|l|l|l|l|l|}
\hline 2011 & 442 & 4 & 4 & 2 & 460 & 32 & 43 & 97 \\
\hline 2012 & 421 & 4 & 5 & 3 & 462 & 29 & 43 & 114 \\
\hline 2013 & 411 & 3 & 10 & 2 & 505 & 33 & 61 & 107 \\
\hline
\end{tabular}

Kaynak: TÜİK İşgücü İstatistikleri Veri Tabanı, http://www.tuik.gov.tr, Erişim Tarihi:11.07.2014.

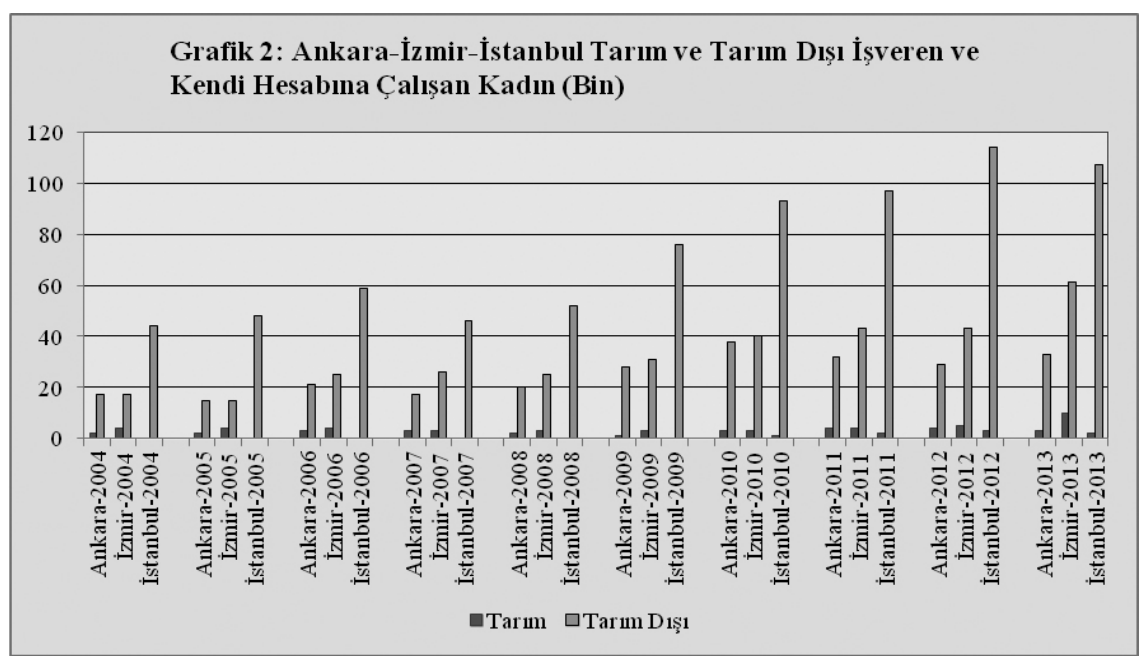

Kaynak: TÜİK İşgücü İstatistikleri Veri Tabanı, http://www.tuik.gov.tr, Erişim Tarihi: 11.07.2014.

\section{Ankara-İzmir-İstanbul'da İşveren ve Kendi Hesabına Çalışan Kadınların Sektörlere Göre Durumu}

Türkiye genelinde 2013 yılında sektörlere göre işveren ve kendi hesabına çalışan toplam kadın sayısı tarımda 411 bin, sanayide 179 bin, hizmetlerde 326 bin'dir (TÜiK İşgücü İstatistikleri Veri Tabanı, http://www. tuik.gov.tr, Erişim Tarihi:11.07.2014). 2013 y1lında Ankara'da sektörlere göre işveren ve kendi hesabına çalışan toplam kadın sayısı tarımda 3 bin, sanayide 8 bin, hizmetlerde 25 bin, İzmir'de sektörlere göre işveren ve kendi hesabına çalışan toplam kadın sayısı tarımda 10 bin, sanayide 20 bin, hizmetlerde 41 bin, İstanbul'da sektörlere göre işveren ve kendi hesabına çalışan toplam kadın sayısı tarımda 2 bin, sanayide 20 bin, hizmetlerde 87 bin'dir (TÜİK İşgücü İstatistikleri Veri Tabanı, http://www.tuik.gov.tr, Erişim Tarihi:11.07.2014). 
YALOVA SOSYAL BİLİMLER DERGİSİ • 175

Tablo 8: Ankara-İzmir-İstanbul'da Sektörlere Göre İşveren ve Kendi Hesabına Çalışan Kadın (Bin)

\begin{tabular}{|l|c|c|c|c|c|c|c|c|c|c|}
\hline Yıllar & $\mathbf{2 0 0 4}$ & $\mathbf{2 0 0 5}$ & $\mathbf{2 0 0 6}$ & $\mathbf{2 0 0 7}$ & $\mathbf{2 0 0 8}$ & $\mathbf{2 0 0 9}$ & $\mathbf{2 0 1 0}$ & $\mathbf{2 0 1 1}$ & $\mathbf{2 0 1 2}$ & $\mathbf{2 0 1 3}$ \\
\hline Ankara & & & & & & & & & & \\
\hline Tarım & 2 & 2 & 3 & 3 & 2 & 1 & 3 & 4 & 4 & 3 \\
\hline Sanayi & 6 & 7 & 7 & 3 & 7 & 7 & 14 & 7 & 6 & 8 \\
\hline Hizmetler & 11 & 8 & 15 & 13 & 13 & 21 & 24 & 25 & 23 & 25 \\
\hline Toplam & 19 & 17 & 24 & 20 & 22 & 29 & 42 & 36 & 34 & 36 \\
\hline İzmir & & & & & & & & & & \\
\hline Tarım & 4 & 4 & 4 & 3 & 3 & 2 & 3 & 4 & 5 & 10 \\
\hline Sanayi & 6 & 3 & 6 & 4 & 4 & 4 & 7 & 13 & 9 & 20 \\
\hline Hizmetler & 11 & 12 & 19 & 22 & 21 & 27 & 33 & 30 & 34 & 41 \\
\hline Toplam & 21 & 19 & 29 & 30 & 28 & 33 & 44 & 47 & 48 & 70 \\
\hline İstanbul & & & & & & & & & & \\
\hline Tarım & 0 & 0 & 0 & 0 & 0 & 0 & 1 & 2 & 3 & 2 \\
\hline Sanayi & 13 & 13 & 15 & 12 & 8 & 9 & 12 & 16 & 21 & 20 \\
\hline Hizmetler & 31 & 35 & 43 & 34 & 43 & 67 & 81 & 81 & 93 & 87 \\
\hline Toplam & 44 & 48 & 59 & 46 & 52 & 76 & 94 & 99 & 117 & 109 \\
\hline
\end{tabular}

Kaynak: TÜIK İşgücü İstatistikleri Veri Tabanı, http://www.tuik.gov.tr, Erişim

Tarihi:11.07.2014. (Rakamlar yuvarlamadan dolayı toplamı vermeyebilir.)

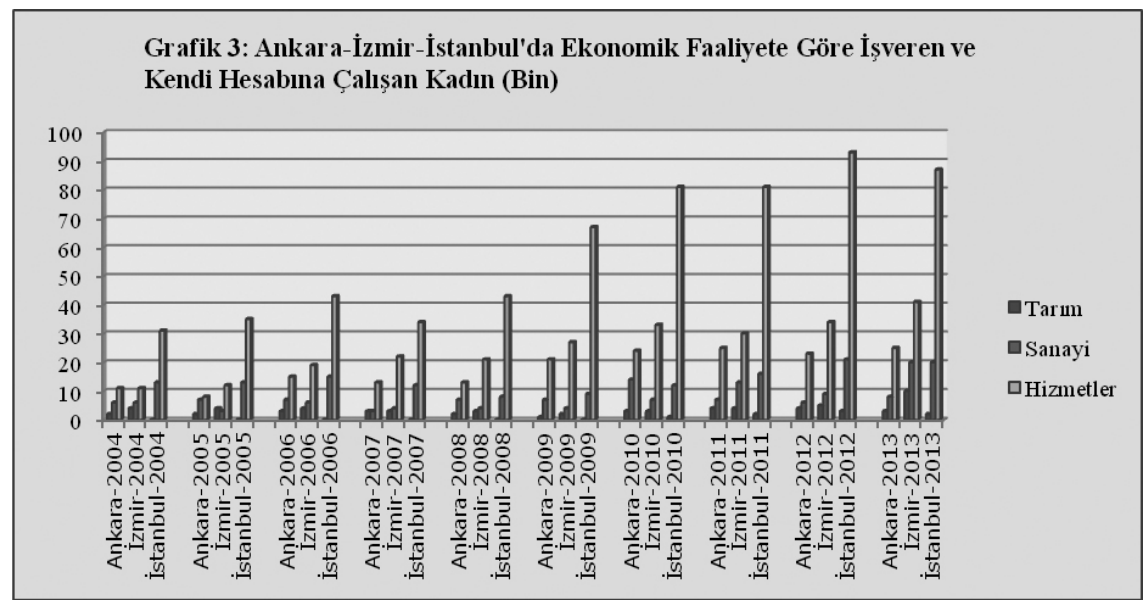

Kaynak: TÜİK İşgücü İstatistikleri Veri Tabanı, http://www.tuik.gov.tr, Erişim Tarihi:11.07.2014. 
2011 y1lında işveren ve kendi hesabına çalışan kadının ekonomik faaliyete göre istihdamında, Ankara'da yüzde 69,2'si hizmetler, yüzde 20,2'si sanayi, yüzde 10,6'sı tarım sektöründe çalıșmaktadır. 2011 yılında ișveren ve kendi hesabına çalışan kadının ekonomik faaliyete göre istihdamında, İzmir'de yüzde 64,3'ü hizmetler, yüzde 27,2'si sanayi ve yüzde 8,5'i tarım sektöründe çalışmaktadır. 2011 yılında işveren ve kendi hesabına çalışan kadının ekonomik faaliyete göre istihdamında, İstanbul'da ise yüzde 81,6's1 hizmetler, yüzde 16,7'si sanayi ve yüzde 1,7'si tarım sektöründe çalışmaktadır (TÜİK Hane Halkı İşgücü İstatistikleri, 2011, s. 242-243-246). Üç ilde sanayi sektöründe işveren ve kendi hesabına çalışan kadınların oranının en yüksek olduğu il İzmir, hizmetler sektöründe İstanbul, tarım sektöründe ise Ankara'dır.

İstihdamın sektörel dağılımı, illerin temel ekonomik faaliyetlerinin yapısının bir göstergesidir. Sadece tarım, sanayi, hizmetler sektörü bazında değerlendirildiğinde üç ilde de işveren ve kendi hesabına çalışan kadın sayısının büyük çoğunluğu hizmetler sektöründe yer almaktadır. Hizmet sektörünü sanayi sektörü takip etmektedir. Tarım son sırada gelmektedir. Gelişmiş illerde, tarım kesiminde çalışanların, toplam istihdam içerisindeki payının göreli olarak düşük olduğu gözlenmektedir. Sosyo-ekonomik gelişmeyle birlikte, toplam istihdam içinde, tarım sektörünün payı göreli olarak gerilerken, sanayi ve hizmetler sektörünün payı artmaktadır. Üç ilin sanayi toplumu kimliğinden çok hizmet toplumu kimliğine bürünmesi, işveren ve kendi hesabına çalışan kadınlarda en büyük payın hizmetler sektöründe olmasında katkısı büyüktür.

Tablo 9: 2011Yılı İşveren ve Kendi Hesabına Çalışan Kadının Sektörlere Göre İstihdamı (\%)

\begin{tabular}{|l|c|c|c|}
\hline \multicolumn{1}{|c|}{ İl } & Tarım \% & Sanayi \% & Hizmet \% \\
\hline Ankara & 10,6 & 20,2 & 69,2 \\
\hline İzmir & 8,5 & 27,2 & 64,3 \\
\hline İstanbul & 1,7 & 16,7 & 81,6 \\
\hline
\end{tabular}

Kaynak: TÜİK Hane Halkı İsgücü İstatistikleri, 2011, s. 242-243-246.

\section{Ankara-İzmir-İstanbul'da İşveren ve Kendi Hesabına Çalışan Kadınların Eğitim Durumu}

Eğitim bireye otonomi, kendine güven ve bağımsızlık kazandırdığı gibi, hak ve sorumluluk bilincinin yükselmesine, kaynak üretme, kazanç elde etme, bilgiye pratik değer kazandırma, her işte ve uğraşta işlevsellik gözetme gibi 
gelişme için gerekli temayüllere açıklık getirir (Aytaç, İlhan, 2007, s.113114).

Eğitim durumu kadınların girişimcilik niyet ve eylemlerini etkileyen faktörlerden biridir. Eğitim durumuna göre işveren ve kendi hesabına çalışan kadın sayısına baktığımızda üç büyük ilimizde, birinci sırada lise altı eğitimlilerin yer aldığını görmekteyiz. İkinci sırada üç ilde de yüksek öğretim görenler yer almaktadır. Bu durum kadın girişimcilerin eğitim düzeyinin yüksek olmadığını ve faaliyet kolları açısından yeterli eğitime sahip olmadıklarını göstermektedir. Buradan anlaşılacağı gibi, kadın girişimciler açısından kendi işini kurmak yeterince eğitim almadığı için ücretli çalışacak bir iş bulamayanların yöneldiği bir alan gibi görülmektedir. Bir başka ifadeyle kadınların girişimci olmayı ekonomik ve sosyal yaşamla bütünleşmenin bir yolu olarak değerlendirmeleri şeklinde açıklanabilir (Yetim, 2002, s.84). İş piyasasına eğitim dezavantajı ile girmeleri halinde, az bilgi ve beceri gerektiren işlere yoğunlaşmak zorunda kalmaktadır, Yine de yüksek öğretim görenlerin ikinci sırada yer alması girişimcilik açısından sevindirici bir gelişme olarak değerlendirilebilir.

Tablo 10: Ankara-İzmir-İstanbul'da Eğitim Durumuna Göre İşveren ve Kendi Hesabına Çalışan Kadın (Bin)

\begin{tabular}{|l|c|c|c|c|c|c|c|c|c|c|}
\hline Yıllar & $\mathbf{2 0 0 4}$ & $\mathbf{2 0 0 5}$ & $\mathbf{2 0 0 6}$ & $\mathbf{2 0 0 7}$ & $\mathbf{2 0 0 8}$ & $\mathbf{2 0 0 9}$ & $\mathbf{2 0 1 0}$ & $\mathbf{2 0 1 1}$ & $\mathbf{2 0 1 2}$ & $\mathbf{2 0 1 3}$ \\
\hline Ankara & & & & & & & & & & \\
\hline $\begin{array}{l}\text { Okuryazar } \\
\text { Olmayan }\end{array}$ & 1 & 1 & 2 & 1 & 1 & 1 & 2 & 2 & 2 & 3 \\
\hline $\begin{array}{l}\text { Lise Altı } \\
\text { Ĕgitim }\end{array}$ & 9 & 9 & 12 & 8 & 10 & 18 & 25 & 20 & 18 & 20 \\
\hline $\begin{array}{l}\text { Lise ve Dengi } \\
\text { Meslek } \\
\text { Okulu }\end{array}$ & 4 & 3 & 5 & 6 & 5 & 4 & 6 & 4 & 6 & 5 \\
\hline $\begin{array}{l}\text { Yüksek } \\
\text { Öğretim }\end{array}$ & 5 & 3 & 5 & 5 & 6 & 6 & 9 & 10 & 8 & 8 \\
\hline Toplam & 19 & 17 & 24 & 20 & 22 & 29 & 42 & 36 & 34 & 36 \\
\hline \begin{tabular}{l} 
İzmir \\
\hline $\begin{array}{l}\text { Okuryazar } \\
\text { Olmayan }\end{array}$
\end{tabular} & 1 & 1 & 2 & 3 & 2 & 2 & 2 & 2 & 2 & 3 \\
\hline $\begin{array}{l}\text { Lise Altı } \\
\text { Eğitim }\end{array}$ & 14 & 12 & 17 & 17 & 13 & 18 & 27 & 28 & 30 & 47 \\
\hline
\end{tabular}


178 • YALOVA SOSYAL BİLİMLER DERGİSİ

\begin{tabular}{|l|c|c|c|c|c|c|c|c|c|c|}
\hline $\begin{array}{l}\text { Lise ve Dengi } \\
\text { Meslek } \\
\text { Okulu }\end{array}$ & 3 & 3 & 5 & 5 & 7 & 7 & 9 & 9 & 7 & 9 \\
\hline $\begin{array}{l}\text { Yüksek } \\
\text { Öğretim }\end{array}$ & 2 & 2 & 5 & 5 & 7 & 6 & 6 & 8 & 10 & 11 \\
\hline Toplam & 21 & 19 & 29 & 30 & 28 & 33 & 44 & 47 & 48 & 70 \\
\hline İstanbul & & & & & & & & & & \\
\hline $\begin{array}{l}\text { Okuryazar } \\
\text { Olmayan }\end{array}$ & 2 & 2 & 3 & 1 & 2 & 5 & 5 & 5 & 8 & 7 \\
\hline $\begin{array}{l}\text { Lise Altı } \\
\text { Eğitim }\end{array}$ & 16 & 24 & 27 & 18 & 19 & 37 & 58 & 62 & 70 & 62 \\
\hline $\begin{array}{l}\text { Lise ve Dengi } \\
\text { Meslek } \\
\text { Okulu }\end{array}$ & 12 & 9 & 12 & 9 & 13 & 13 & 12 & 12 & 16 & 18 \\
\hline $\begin{array}{l}\text { Yüksek } \\
\text { Ŏğretim }\end{array}$ & 14 & 13 & 16 & 18 & 18 & 21 & 19 & 20 & 24 & 22 \\
\hline Toplam & 44 & 48 & 59 & 46 & 52 & 76 & 94 & 99 & 117 & 109 \\
\hline
\end{tabular}

Kaynak: TÜİK, İşüicü İstatistikleri Veri Tabanı, http://www.tuik.gov.tr, Erişim Tarihi:12.07.2014. (Rakamlar yuvarlamadan dolayı toplamı vermeyebilir.)

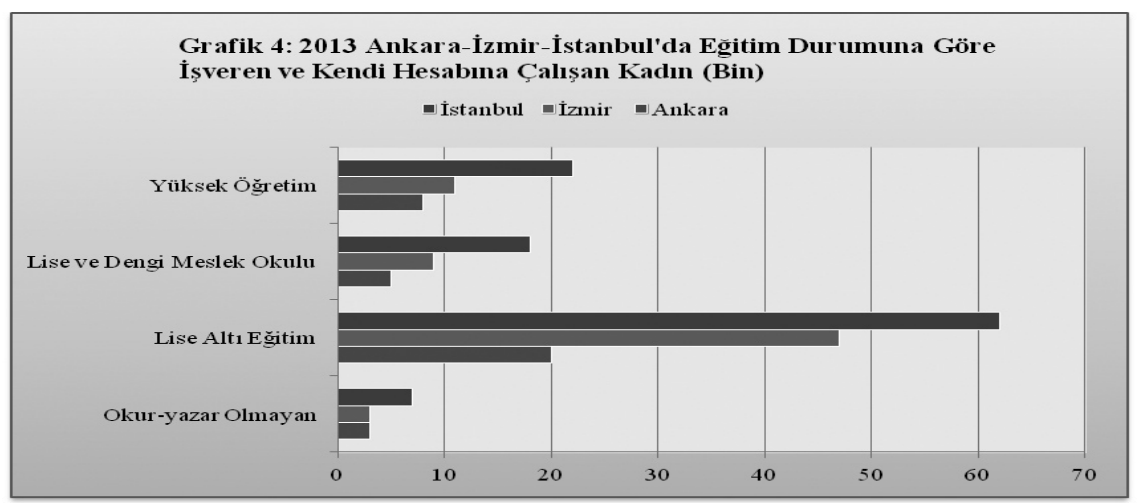

Kaynak: TÜİ, İşgücü İstatistikleri Veri Tabanı, http://www.tuik.gov.tr, Erişim Tarihi:12.07.2014.

\section{Ankara-İzmir-İstanbul'da İşveren ve Kendi Hesabına Çalışan Kadınların İşyeri Büyüklüğüne Göre Durumu}

Üç büyük ilimizde işletmelerin genel yapısına baktığımızda küçük ölçekli işletmelerin büyük bir çoğunluğu oluşturduğu dikkatimizi çekiyor. Kadın girişimcilerin sahip olduğu işletmeler 1-9 kişinin çalıştığ 1 mikro ölçekli işletmelerdir. Bu bize kadın girişimcilerin küçük ölçekli az sermaye gerektiren işlere 
yöneldiğini göstermektedir. Bunun en büyük nedenlerinden biri kadın girişimcilerin yatırımları için bulabilecekleri finansal kaynakların yetersizliğidir. Tüm bu göstergeler göz önünde tutulduğunda, ülkemizde kadın girişimcilik potansiyeli açısından mikro işletmelerin önde geldiği açık olarak görülmektedir. Bu olgu aynı zamanda ülkemizde kadın girişimciliğinin geliştirilmesi için KOBİ'lerin önemini de ortaya koymaktadır.

Tablo 11: Ankara-İzmir-İstanbul'da İşyeri Büyüklüğüne Göre İşveren ve Kendi Hesabına Çalışan Kadın (Bin)

\begin{tabular}{|l|c|c|c|c|c|c|c|c|c|c|}
\hline Yıllar & $\mathbf{2 0 0 4}$ & $\mathbf{2 0 0 5}$ & $\mathbf{2 0 0 6}$ & $\mathbf{2 0 0 7}$ & $\mathbf{2 0 0 8}$ & $\mathbf{2 0 0 9}$ & $\mathbf{2 0 1 0}$ & $\mathbf{2 0 1 1}$ & $\mathbf{2 0 1 2}$ & $\mathbf{2 0 1 3}$ \\
\hline Ankara & & & & & & & & & & \\
\hline $\mathbf{1 - 9}$ & 19 & 17 & 24 & 19 & 21 & 29 & 41 & 35 & 33 & 35 \\
\hline $\mathbf{2 0 - 2 4}$ & 0 & 0 & 0 & 0 & 0 & 0 & 0 & 0 & 1 & 1 \\
\hline $\mathbf{2 5 - 4 9}$ & 0 & 0 & 0 & 0 & 0 & 0 & 0 & 0 & 0 & 0 \\
\hline $\mathbf{5 0 +}$ & 0 & 0 & 0 & 0 & 0 & 0 & 0 & 0 & 0 & 0 \\
\hline İzmir & & & & & & & & & & \\
\hline $\mathbf{1 - 9}$ & 20 & 19 & 28 & 29 & 27 & 32 & 42 & 45 & 46 & 68 \\
\hline $\mathbf{2 0 - 2 4}$ & 0 & 0 & 0 & 1 & 1 & 0 & 1 & 1 & 1 & 1 \\
\hline $\mathbf{2 5 - 4 9}$ & 0 & 0 & 0 & 0 & 0 & 0 & 0 & 0 & 1 & 0 \\
\hline $\mathbf{5 0 +}$ & 0 & 0 & 1 & 0 & 0 & 0 & 0 & 1 & 0 & 0 \\
\hline İstanbul & & & & & & & & & & \\
\hline $\mathbf{1 - 9}$ & 41 & 46 & 53 & 42 & 49 & 74 & 91 & 95 & 114 & 103 \\
\hline $\mathbf{2 0 - 2 4}$ & 2 & 0 & 3 & 2 & 1 & 1 & 2 & 1 & 2 & 4 \\
\hline $\mathbf{2 5 - 4 9}$ & 1 & 1 & 2 & 1 & 2 & 1 & 1 & 2 & 1 & 1 \\
\hline $\mathbf{5 0}+$ & 0 & 0 & 1 & 1 & 0 & 0 & 1 & 1 & 0 & 1 \\
\hline
\end{tabular}

Kaynak: TÜİK İşgücü İstatistikleri Veri Tabanı, http://www.tuik.gov.tr, Erişim Tarihi:12.07.2014.

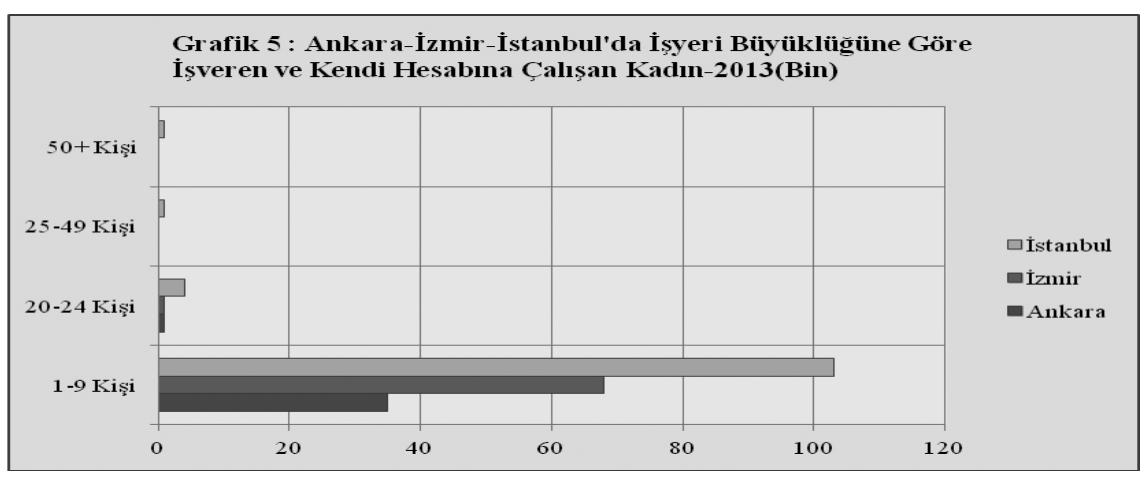

Kaynak: TÜİK İşgücü İstatistikleri Veri Tabanı, http://www.tuik.gov.tr, Erişim Tarihi:12.07.2014. 
$180 \bullet$ YALOVA SOSYAL BİLİMLER DERGİSİ

\section{Ankara-İzmir-İstanbul'da İşveren ve Kendi Hesabına Çalışan}

\section{Kadınların Yaş Gruplarına Göre Durumu}

Üç büyük ilimizde işveren ve kendi hesabına çalışan kadınların geniş yaş grubuna göre dağılımına baktığımızda Ankara, İzmir ve İstanbul'da büyük çoğunluğun 35-54 yaş diliminde olduğunu yani kadın girişimcilerin önemli bir kısmının orta yaşlı olduğu görülüyor. Kadın girişimcilerin orta yaşlı olması, bu üç ilimizde kadın girişimci profilini evli ve çocuklu olarak çizmektedir. Ayrıca bu durumda, girişimci kadınların önce başka işlerle uğraştıkları ya da çocuklarını belirli bir yaşa getirdikten sonra tekrar iş yaşamına dönmeleri de etkili olmaktadır. Oysa genç kadın girişimciliği ülkemiz gibi gelişmekte olan toplumlar açısından desteklenmesi gereken önemli bir husustur.

Tablo 12: Ankara-İzmir-İstanbul'da Geniş Yaş Grubuna Göre İşveren ve Kendi Hesabına Çalışan Kadın (Bin)

\begin{tabular}{|l|c|c|c|c|c|c|c|c|c|c|}
\hline Yıllar & $\mathbf{2 0 0 4}$ & $\mathbf{2 0 0 5}$ & $\mathbf{2 0 0 6}$ & $\mathbf{2 0 0 7}$ & $\mathbf{2 0 0 8}$ & $\mathbf{2 0 0 9}$ & $\mathbf{2 0 1 0}$ & $\mathbf{2 0 1 1}$ & $\mathbf{2 0 1 2}$ & $\mathbf{2 0 1 3}$ \\
\hline Ankara & & & & & & & & & & \\
\hline $\begin{array}{l}\text { 15-19 Yaş } \\
\text { Dilimi }\end{array}$ & 0 & 0 & 0 & 0 & 0 & 0 & 0 & 0 & 0 & 0 \\
\hline $\begin{array}{l}\text { 20-24 Yaş } \\
\text { Dilimi }\end{array}$ & 1 & 1 & 0 & 0 & 1 & 1 & 1 & 1 & 0 & 1 \\
\hline $\begin{array}{l}\text { 25-34 Yaş } \\
\text { Dilimi }\end{array}$ & 5 & 6 & 8 & 6 & 7 & 8 & 12 & 9 & 10 & 9 \\
\hline $\begin{array}{l}\text { 35-54 Yaş } \\
\text { Dilimi }\end{array}$ & 12 & 8 & 14 & 12 & 13 & 18 & 24 & 22 & 20 & 22 \\
\hline 55+ Yaş Dilimi & 1 & 2 & 3 & 1 & 1 & 2 & 4 & 3 & 4 & 4 \\
\hline
\end{tabular}

\begin{tabular}{|l|c|c|c|c|c|c|c|c|c|c|}
\hline Izmir & & & & & & & & & & \\
\hline $\begin{array}{l}\text { 15-19 Yaş } \\
\text { Dilimi }\end{array}$ & 0 & 0 & 0 & 0 & 0 & 0 & 0 & 0 & 0 & 0 \\
\hline $\begin{array}{l}\text { 20-24 Yaş } \\
\text { Dilimi }\end{array}$ & 1 & 1 & 2 & 2 & 0 & 2 & 2 & 2 & 1 & 3 \\
\hline $\begin{array}{l}\text { 25-34 Yaş } \\
\text { Dilimi }\end{array}$ & 6 & 5 & 7 & 7 & 8 & 8 & 10 & 12 & 14 & 21 \\
\hline $\begin{array}{l}\text { 35-54 Yaş } \\
\text { Dilimi }\end{array}$ & 11 & 10 & 17 & 18 & 17 & 20 & 25 & 26 & 26 & 38 \\
\hline 55+ Yaş Dilimi & 3 & 3 & 3 & 3 & 3 & 4 & 5 & 8 & 8 & 9 \\
\hline
\end{tabular}

\begin{tabular}{|l|c|c|c|c|c|c|c|c|c|c|}
\hline Ístanbul & & & & & & & & & & \\
\hline $\begin{array}{l}\text { 15-19 Yaş } \\
\text { Dilimi }\end{array}$ & 1 & 0 & 0 & 0 & 0 & 0 & 1 & 0 & 1 & 1 \\
\hline
\end{tabular}


YALOVA SOSYAL BİLİMLER DERGİSİ • 181

\begin{tabular}{|l|c|c|c|c|c|c|c|c|c|c|}
\hline $\begin{array}{l}\text { 20-24 Yaş } \\
\text { Dilimi }\end{array}$ & 3 & 3 & 2 & 1 & 2 & 3 & 3 & 3 & 4 & 5 \\
\hline $\begin{array}{l}\mathbf{2 5 - 3 4} \text { Yaş } \\
\text { Dilimi }\end{array}$ & 15 & 15 & 21 & 16 & 18 & 18 & 25 & 26 & 33 & 25 \\
\hline $\begin{array}{l}\text { 35-54 Yaş } \\
\text { Dilimi }\end{array}$ & 22 & 26 & 32 & 27 & 29 & 51 & 60 & 64 & 72 & 69 \\
\hline $\mathbf{5 5}+$ Yaş Dilimi & 3 & 4 & 3 & 2 & 3 & 4 & 6 & 6 & 8 & 9 \\
\hline
\end{tabular}

Kaynak: TÜİK İşgücü İstatistikleri Veri Tabanı, http://www.tuik.gov.tr, Erişim Tarihi:12.07.2014.

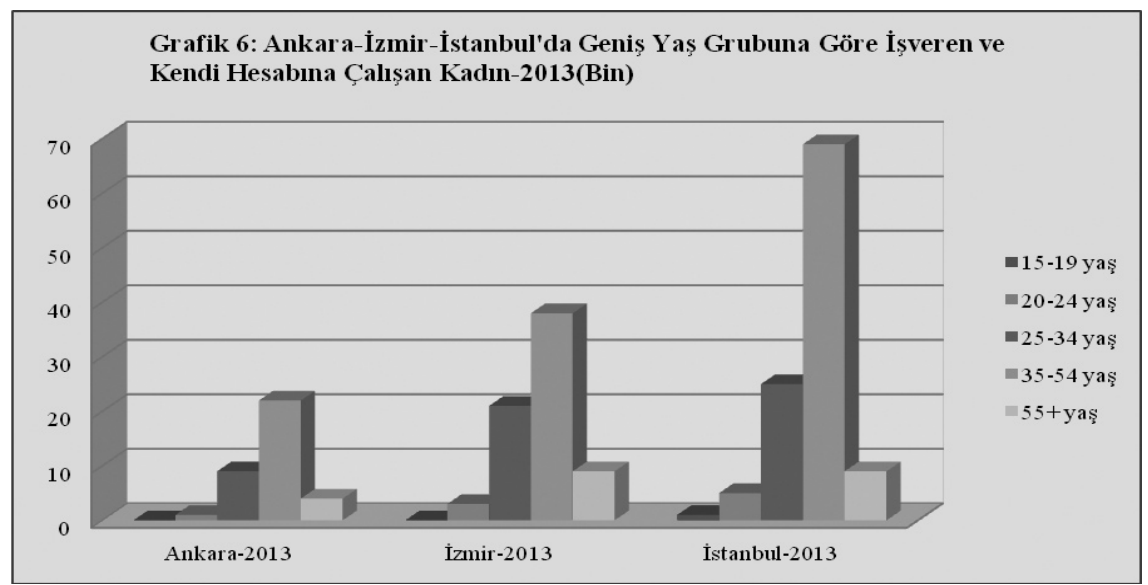

Kaynak: TÜİK İşgücü İstatistikleri Veri Tabanı, http://www.tuik.gov.tr, Erişim Tarihi:12.07.2014.

\section{Ankara-İzmir-İstanbul'da İşveren ve Kendi Hesabına Çalışan}

\section{Kadınların Sosyal Güvenlik Durumu}

Ülke geneline baktığımızda kayıt dışı çalışanların işveren kadınlarda daha düşük olduğunu söylemek mümkündür. 2013 yılında işveren kadınların 13 bini kayıt dışı çalışırken 82 bini kayıtlı çalışmaktadır (TÜİK İşgücü İstatistikleri Veri Taban1, http://www.tuik.gov.tr, Erişim Tarihi:12.07.2014). Kendi hesabına çalışan kadınlarda ise durum tersinedir. Kendi hesabına çalışan kadınların büyük çoğunluğu kayıt dışı çalışmaktadır. 2013 yılında kendi hesabına çalışan kadınların 730 bini kayıt dışı çalışırken 91 bini kayıtlı olarak çalışmaktadır (TÜİK İşgücü İstatistikleri Veri Tabanı, http://www.tuik.gov.tr, Erişim Tarihi:12.07.2014). 
182・ YALOVA SOSYAL BİLİMLER DERGİSİ

Tablo 13: Türkiye'de İşveren, Kendi Hesabına Çalışan Kadının Sosyal Güvenlik Kurumuna Kayıtlı Olup-Olmama Durumu (Bin)

\begin{tabular}{|c|c|c|c|c|}
\hline \multirow{2}{*}{ Yıllar } & \multicolumn{2}{|c|}{ İşveren } & \multicolumn{2}{c|}{ Kendi Hesabına Çalışan } \\
\cline { 2 - 5 } & Kayıtlı Değil & Kayıtlı & Kayıtlı Değil & Kayıtlı \\
\hline 2004 & 14 & 35 & 443 & 48 \\
\hline 2005 & 18 & 32 & 610 & 58 \\
\hline 2006 & 23 & 46 & 590 & 69 \\
\hline 2007 & 21 & 54 & 563 & 54 \\
\hline 2008 & 26 & 52 & 559 & 58 \\
\hline 2009 & 24 & 53 & 683 & 67 \\
\hline 2010 & 22 & 61 & 746 & 76 \\
\hline 2011 & 20 & 67 & 731 & 85 \\
\hline 2012 & 18 & 75 & 706 & 82 \\
\hline 2013 & 13 & 82 & 730 & 91 \\
\hline
\end{tabular}

Kaynak: TÜİK İşgücü İstatistikleri Veri Tabanı, http://www.tuik.gov.tr, Erişim Tarihi:12.07.2014.

Aşağıda tablo 14'de görüldüğü gibi, Ankara, İzmir, İstanbul'da işveren ve kendi hesabına çalışan kadınların büyük bölümü kayıt dışı çalışmaktadır. Bunun nedeni kendi hesabına çalışan kadınlarda kayıt dışı çalışanların yüksek olmasidir.

Tablo 14: Ankara-İzmir-İstanbul'da Sosyal Güvenlik Kurumuna Kayitlı Olup-Olmama Durumuna Göre İşveren ve Kendi Hesabına Çalışan Kadın (Bin)

\begin{tabular}{|c|c|c|c|c|c|c|}
\hline \multirow{2}{*}{ Yıllar } & \multicolumn{2}{|c|}{ Ankara } & \multicolumn{2}{c|}{ Izmir } & \multicolumn{2}{c|}{ İstanbul } \\
\cline { 2 - 7 } & Kayıtlı Değil & Kayıtlı & Kayıtlı Değil & Kayıtlı & $\begin{array}{c}\text { Kayıtlı } \\
\text { Değil }\end{array}$ & Kayıtlı \\
\hline 2004 & 13 & 7 & 15 & 6 & 23 & 22 \\
\hline 2005 & 11 & 6 & 12 & 7 & 31 & 17 \\
\hline 2006 & 18 & 6 & 17 & 12 & 31 & 28 \\
\hline 2007 & 12 & 8 & 17 & 13 & 21 & 25 \\
\hline 2008 & 14 & 7 & 14 & 14 & 23 & 29 \\
\hline 2009 & 22 & 7 & 22 & 11 & 46 & 30 \\
\hline 2010 & 30 & 11 & 30 & 13 & 64 & 30 \\
\hline 2011 & 23 & 13 & 32 & 15 & 61 & 37 \\
\hline 2012 & 22 & 12 & 30 & 19 & 77 & 40 \\
\hline 2013 & 23 & 13 & 50 & 20 & 68 & 40 \\
\hline
\end{tabular}

Kaynak: TÜİK İşgücü İstatistikleri Veri Tabanı, http://www.tuik.gov.tr, Erişim Tarihi:12.07.2014 


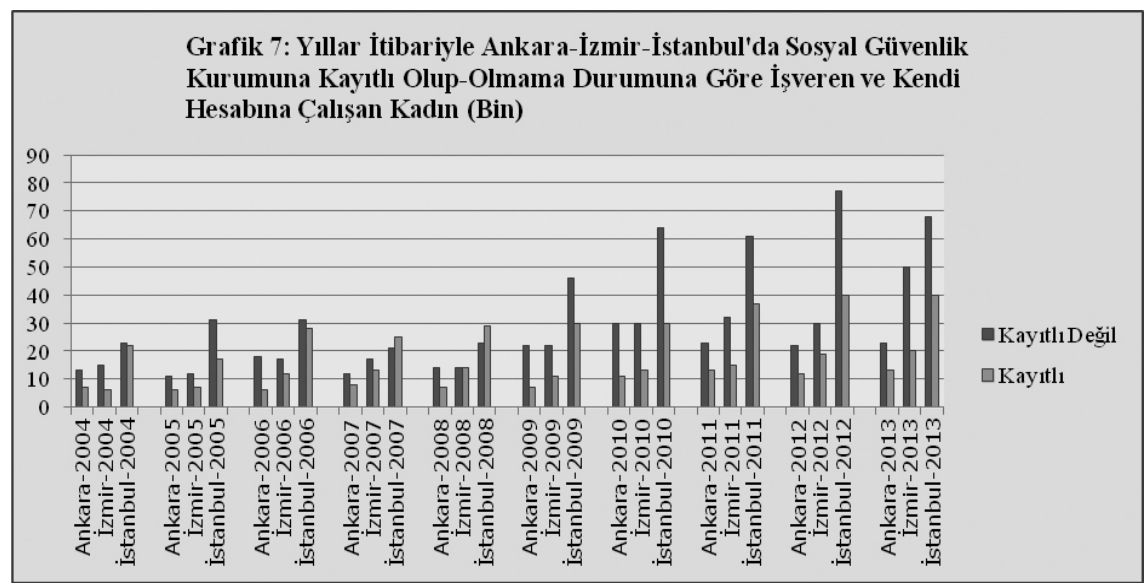

Kaynak: TÜİK İşgücü İstatistikleri Veri Tabanı, http://www.tuik.gov.tr, Erişim Tarihi:12.07.2014.

\section{Ankara-İzmir-İstanbul'da Kadın Girişimciliği, GZFT (Güçlü-Zayıf-Fırsat-Tehdit-SWOT) Analizi}

\section{Güçlü yanlar(Strengths)}

$>$ Genç ve dinamik kadın işgücü potansiyeli

$>$ Yetişmiş-nitelikli kadın işgücü

> Tüm sektörlerde iyi eğitimli profesyonel çalışan kadın sayısının artmas1

$>$ Tarım sektörü istihdam payının küçüklügüü

$>$ Ücretli ve maaşlı kadın istihdamının Türkiye ortalamasına göre yüksekliği

> Mesleki eğitime olan talebin giderek artması ve kadın girişimciliği ile ilgili eğitim programlarının varlığ 1

$>$ Başarılı rol modellerin bulunması

$>$ Girişimci kadınlar arasında yüksek öğrenim görenlerin sayısındaki $\operatorname{artış~}$

\section{Zayıf Yanlar (Weaknesses)}

> Kadınların sahip olduğu nitelikler arasındaki uçurumun fazla olması

$>$ Gelir dağılımı arasındaki fark 
184 • YALOVA SOSYAL BİLİMLER DERGİSİ

$>$ Nitelikli kadın işgücüne kaliteli iş firsatlarının yeterli seviyede olmamas1

> Yenilikçi girişimciye yardımcı olacak mekanizmalar eksikliği

\section{Firsatlar (Opportunities)}

$>$ Ekonominin, sanayinin ve ticaretin merkezi olmaları

$>$ Gelişmiş hizmet sektörü

> Ekonomik faaliyetler ve katma değer açısından Türkiye'nin en büyük kentleri

> Gelişmiş teknoloji altyapısı

$>$ Güçlü finans ve bankacilık altyapısı

> Sivil toplum kuruluşlarının ve yerel yönetimlerin mesleki eğitime olumlu bakış açısına sahip olmaları

> Gelişmiş ve günümüz şartlarına adapte edilmiş ulaşım imkanları

> Gelişmeye açık ve sürekli büyüyen iç pazarlar

$>$ Nitelikli üniversitelerin varlığ

> Türkiye'de toplam nüfusa oranla en çok yüksek öğretim nüfusu barındirmalar1

\section{Tehditler (Threats)}

$>$ Yıllık nüfus artış hızının Türkiye ortalamasının üstünde olması

$>$ İstihdam oranının düşüklüğü

$>$ İşsizlik oranının yüksekliği

$>$ Yerli ve yabancı göç alıyor olmaları

> Belediyelerin kentsel altyapılarının yetersizliği ve hızlı talep artışının beraberinde getirdiği ihtiyaçlara cevap verememesi

$>$ Yatırım için altyapı maliyetlerinin yüksekliği

> Mekansal eşitsizliklerin fazlalığı

\section{Sonuç}

TÜİK verilerinden yararlanarak, Ankara, İzmir, İstanbul illerinde kadın girişimcilere baktığımızda elde edilen sonuçlara göre;

İstanbul'da hemen hemen tamamının Ankara ve İzmir'de de büyük çoğunluğun tarım dışı alanlarda çalıştığı görülmektedir. Türkiye'de 2013 yılında tarım dişı alanda işveren ve kendi hesabına çalışan kadınların yüzde 39,8'i 
İstanbul, İzmir ve Ankara'da bulunmaktadır. Türkiye' de 2013 yılında tarımda işveren ve kendi hesabına çalışan kadınların yüzde 3,6'ü Ankara, İzmir ve İstanbul'da bulunmaktadir.

İstihdamın sektörel dağılımı, illerin temel ekonomik faaliyetlerinin yapıs1nın bir göstergesidir. Sadece tarım, sanayi, hizmetler sektörü bazında değerlendirildiğinde üç ilde de işveren ve kendi hesabına çalışan kadın sayısının büyük çoğunluğu hizmetler sektöründe yer almaktadır. Hizmet sektörü düşük başlangıç sermaye gereksinimi, giriş engelinin az olması vb. nedenlerle kadın girişimcilerin yöneldiği sektör olmaktadır. Hizmet sektörünü sanayi sektörü takip etmektedir. Tarım son sırada gelmektedir.

Eğitim durumuna göre işveren ve kendi hesabına çalışan kadın sayısına baktığımızda üç büyük ilimizde, birinci sırada lise altı eğitimlilerin yer aldığ1nı görmekteyiz. İkinci sırada yüksek öğretim görenler yer almaktadır. Yüksek öğretim görenlerin ikinci sırada yer alması girişimcilik açısından sevindirici bir gelişme olarak değerlendirilebilir.

Üç büyük ilimizde, kadın girişimciliğinde işletmelerin genel yapısına baktığımızda küçük ölçekli işletmeler büyük çoğunluğu oluşturmaktadır. Kadın girişimcilerin sahip olduğu işletmeler 1-9 kişinin çalıştığı mikro ölçekli işletmelerdir. Bu bize kadın girişimcilerin küçük ölçekli az sermaye gerektiren işlere yöneldiğini göstermektedir. Bunun en büyük nedenlerinden biri kadın girişimcilerin yatırımları için bulabilecekleri finansal kaynakların yetersizliğidir. Bu göstergeler göz önünde tutulduğunda, ülkemizde kadın girişimcilik potansiyeli açısından mikro işletmelerin en önde geldiği açık olarak görülmektedir.

Üç büyük ilimizde, kadın girişimcilerin önemli bir kısmının orta yaş grubunda olduğu görülmektedir.

Üç büyük ilimizde, işveren ve kendi hesabına çalışan kadınların büyük bölümü kayıt dışı çalışmaktadır. Bunun nedeni kendi hesabına çalışan kadınlarda kayıt dışı çalışanların yüksek olmasıdır. 


\section{KAYNAKÇA}

Aytaç, Ömer ve İlhan, Süleyman , 'Girişimcilik ve Girişimci Kültür: Sosyolojik Bir Perspektif”, Selçuk Üniversitesi Sosyal Bilimler Enstitüsü Dergisi, Sayı: 18, 2007.

Çakıcı, Ayşehan, 'Mersin'deki Kadın Girişimcilerin İş Yaşamını Etkileyen Faktörler”, Dokuz Eylül Üniversitesi Sosyal Bilimler Enstitüsü Dergisi, Cilt 8, Sayı:4, 2006

http://www.istanbul.gov.tr/images/docs/ii-Rapor-enson-1ppt, Erişim Tarihi:08.07.2014.

Kulaksız, Yahya, 'Türkiye'de Bölgesel Gelişmişlik Farkları, İstihdam ve Kurum Hizmetlerinin Çeşitlendirilmesi”, Çalıșma ve Sosyal Güvenlik Bakanlığı-Türk İş Kurumu Uzmanlık Tezi, Ankara, 2008.

TEPAV, “'̇̇stihdam İzleme Bülteni,” Haber Bülteni, 05.05.2012, Say1 6.

TÜIK, Bölgesel Göstergeler TR 512009 Ankara, Ankara, Yayın No:3418, Nisan 2010.

TÜIK, Bölgesel Göstergeler TR 312009 İzmir, Ankara, Yayın No:3394, Nisan 2010.

TÜIK, Bölgesel Göstergeler TR 102009 İstanbul, Ankara, Yayın No:3388, Nisan 2010.

TÜIK, Bölgesel Göstergeler TR 512012 Ankara, Ankara, Yayın No:4037, Eylül 2013.

TÜİK, Bölgesel Göstergeler TR 312012 İzmir, Ankara, Yayın No:4053, Eylül 2013.

TÜIK, Bölgesel Göstergeler TR 102012 İstanbul, Ankara, Yayın No:4031, Eylül 2013.

TÜIK,, Bölgesel Göstergeler TR 512013 Ankara, Ankara, Yayın No:4226, Eylül 2014.

TÜIK, Bölgesel Göstergeler TR 312013 İzmir, Ankara, Yayın No:4194, Eylül 2014.

TÜIK, Bölgesel Göstergeler TR 102013 İstanbul, Ankara, Yayın No:4182, Eylül 2014.

TÜİK, Haber Bülteni, Adrese Dayalı Nüfus Kayıt Sistemi Sonuçları, Sayı:15974, 29.01.2014.

TÜIK, Haber Bülteni, Hanehalkı İşgücü İstatistikleri, 2013, Sayı:16015, 06.03.2014.

TÜİK, Hane Halkı İşgücü İstatistikleri 2011, Ankara, Yayın No:3684, Haziran 2012.

TÜİK, Türkiye İstatistik Yıllığı 2009, Ankara, Yayın No:3436, Mayıs 2010.

TÜIK, Türkiye İstatistik Yıllığı 2011, Ankara, Yayın No:3665, Nisan 2012.

TÜİK, Türkiye İstatistik Yıllığı 2012, Ankara, Yayın No:3933, Haziran 2013.

TÜİK, Nüfus İstatistikleri, http://www.tuik.gov.tr, Erişim Tarihi: 09.07.2014.

TÜIK, İşgücü İstatistikleri Veri Tabanı, http://www.tuik.gov.tr,ErişimTarihi: 09.07.2014, 11.07.2014, 12.07.2014.

TÜIK, İstatistik Göstergeler 1923-2009, Ankara, Yayın No:3493, Aralık 2010.

Türkyılmaz, Ufuk, 'Ekonomi Canlı Diplomalılar İşsiz," Akşam, 28.Aralık.2010.Salı, www.aksam.com.tr/ekonomi- canli-diplomalilar-issiz--6811h.html, Erişim Tarihi:08.07.2014.

Yetim, Nalan, 'Sosyal Sermaye Olarak Kadın Girişimciler: Mersin Örneği”, Ege Akademik Bakış Dergisi, Cilt 2, Sayı1, 2002. 